\title{
The effect of storytelling on fear in school-age children during hospitalization
}

\author{
Martina Mutiara Dewi,1 Nani Nurhaeni,2 Happy Hayati2 \\ ${ }^{1}$ Faculty of Nursing, Universitas Indonesia, Depok; 'Department of Pediatric Nursing, Faculty of Nursing, Universitas \\ Indonesia, Depok, Indonesia
}

\begin{abstract}
Hospitalization places children in conditions that may nurture fears of new surroundings, strangers, and unknown actions.
\end{abstract}

Correspondence: Nani Nurhaeni, Department of Pediatric Nursing, Faculty of Nursing, Universitas Indonesia, Jalan Prof. Dr. Bahder Djohan, UI Campus, West Java, 16424 Depok, Indonesia Tel.: +62.21.78849120; Fax: +62.21.7864124

E-mail: nani-n@ui.ac.id

Key words: Child; hospitalization; pediatric; storytelling.

Acknowledgments: Thanks to Direktorat Riset dan Pengembangan Universitas Indonesia

Contributions: MMD, NN, and HH conceived the idea and plan of research. All authors discussed the results and reviewed the final manuscript.

Conflic of interests: The authors declare no conflict of interests.

Funding: This work was supported by HIBAH PUTI Saintekes from Direktorat RisBang Universitas Indonesia (No : NKB-

4601/UN2.RST/HKP.05.00/2020)

Conference presentation: This final manuscript has been presented at 7th Virtual Biennial International Nursing Conference, Faculty of Nursing, Universitas Indonesia on September 24th, October 30th, November 16th 2020 .

Availability of data and materials: All data generated or analyzed during this study are included in this published article.

Ethics approval and consent to participate: The Ethics Committee of the Faculty of Nursing Universitas Indonesia approved this study (SK-23/UN2.F12.D1.2.1/ETIK.FIK.2020). The study is conformed with the Helsinki Declaration of 1964, as revised in 2013, concerning human and animal rights. All patients participating in this study signed a written informed consent form for participating in this study.

Consent for publication: Written informed consent was obtained from a legally authorized representative(s) for anonymized patient information to be published in this article.

Received for publication: 15 August 2020.

Accepted for publication: 30 April 2021.

This work is licensed under a Creative Commons Attribution

NonCommercial 4.0 License (CC BY-NC 4.0).

CCopyright: the Author(s), 2021

Licensee PAGEPress, Italy

La Pediatria Medica e Chirurgica 2021; 43(s1):269

doi:10.4081/pmc.2021.269
Storytelling can be administered as a distraction from the fears that a child experiences during treatment. This study aims to determine the effectiveness of storytelling against fear due to hospitalization in school-age children admitted to the hospital. This study used a quantitative approach with a pre-experimental design and the method used was nonequivalent control group pretest-posttest design. Subjects in this study consisted of two groups namely the intervention and the control groups. The total number of respondents was $n=32$ and located at the Maternity and Children Hospital in Indonesia. Bivariate analysis showed that storytelling intervention had a significant relationship with the fear of hospitalization among the hospitalized school-age children ( $p$-value $=0.001<0.05)$. Also, there was a significant difference between the fear score in the intervention and the control groups $(p$-value $=0.001<)$. Therefore, applying storytelling in the nursing intervention of pediatric patients in hospitals can be recommended to minimize the fear in children.

\section{Introduction}

According to the Indonesian Health Profile data from the Ministry of Health in 2018, the estimated number of school-aged children (7-12 years) in Indonesia is around 28,125,485 people or $10.6 \%$ of the total population. School-age children begin to interact and play with their peers, hospitalization can be obstacle their growth and development because children cannot meet and socialize with their friends, and these children experience anxiety and stress. ${ }^{1-3}$ The child's fear during treatment can be reduced by applying atraumatic care during nursing interventions. Atraumatic care includes playing, telling stories, storytelling, or other distraction techniques that can reduce the fear of children.4-5

Research conducted in Iran on children who underwent surgery said that reading animated storybooks in children aged 4-8 years was effective in reducing anxiety and behavioral disorders after surgery. ${ }^{6}$ Another similar study explains that using cognitive behavioral program, storytelling and imagination guidance have a significant effect on reducing the level of anxiety and fear of children who are subjected to invasive action (infusion). ${ }^{7,8}$ Storytelling by parents to children will make children feel comfortable, children feel at home were listening to stories can reduce anxiety and fear, likewise in adults.9-11 Children's anxiety due to hospitalization varies depending on their level of maturity development, separation from parents/hospitalization history, and availability of a support system Assessing the child's previous experiences are fundamental in identifying the appropriate interventions to reduce anxiety and distress to support effective coping. ${ }^{12,13}$ Storytelling can be used as an option in nursing interventions in pediatric patients in the hospital so that the negative responses of children that arise during treatment can be 
reduced.6,7,9 Based on some of the studies above and the large proportion of school-age children in Indonesia and the lack of research related to storytelling on the fear of hospitalization for school-age children, it is felt necessary to conduct research related to the effectiveness of storytelling on the fear of hospitalizing school-age children in hospitals.

\section{Materials and Methods}

\section{Design}

The design used in this study was a pre-experiment with a nonequivalent control group pretest-posttest design method. The intervention carried out was treatment with storytelling, with pre-test and post-test to observe the level of fear of hospitalization among school-age children.

\section{Sample and setting}

The sample used was all school-age children hospitalized in Maternity and Children Hospital in Indonesia who met the following inclusion criteria: i) children aged 6 to 10 years; ii) children who are admitted to hospital and had received treatment within 12 days; iii) children who can communicate well, listen and see, as well as understand instructions; iv) children who have a minimum score 1 (pretest) of fear towards hospitalization. The exclusion criteria were as follows: i) children who experience sudden levels of reduced consciousness, bleeding, seizures, shortness of breath, or other hemodynamic disturbances that require emergency treatment; ii) children/parents who did not want to continue with the research process. The sample in this study was taken using a consecutive sampling technique with 32 respondents with the number of each group was 16 (Table 1). The research was conducted from March to July 2020 by holding the principles of beneficence, respect for human dignity, and justice which are applied in the use of informed consent. The data collection tools used was a questionnaire in the form of a Children's Fear measurement Scale (CFS) to assess the modified fear score and translated into Indonesian through the Language Institute of the University of Indonesia on January 9, 2020.

\section{Data collection}

\section{Intervention}

The applied methodology in the intervention group used picture books, namely the series "Ketika Aku Sakit" [When I'm Sick] which consists of 6 stories about sick children which, during the intervention, can be selected according to the respondents' wishes. Each book covers different themes which were "Cough", "Fever", "Diarrhea", "Chickenpox", "Eye Conjungtivitis" and "Tooth Cavities". The CFS consists of five facial images that expressed children's fear. Each of the images contains meaning; the face that expresses no fear has the score of 0 , the one that expresses a little fear has the score of 1 , another that expresses a little more fear has the score of 2, the one that expresses fear has the score of 3 , the one that expresses the most fear has the score of 4 . The lesser the score value means the lesser the fear felt by the respondents. Similarly, a greater score value indicates greater fear. The construct validity of the CFS instrument used in this research has been proven where it had $R_{s}$ value (100) 0.73 and p-value $<0.001$ in the previous studies. While the reliability test results of the CFS instrument in the previous study were $\mathrm{R}_{\mathrm{s}}(48)=0.76$ with $\mathrm{p}$-value $<0.001$. The researcher was assisted by 2 people who had met the criteria as research assistants before the research began. Inter-rater tests on the storytelling intervention were not carried out due to the unavailability of a measurement scale for the storytelling of which equality can be assessed. Data collection was carried out through both administrative and technical procedures. Then, the data is analyzed using a statistical software package with univariate and bivariate analysis.

\section{Measurement}

Univariate analysis was used to explain the respondents' characteristics which included: age, gender, previous experience with hospitalization, inpatient companion, and the ward class for hospitalization.

\section{Data analysis}

The type of normality test on numerical data utilizes the Shaphiro-Wilk test on the fear variable. The fear scores before and after intervention on both the intervention and control group gained from the test showed a normal distribution of data. The

Table 1. Table of characteristics of school-age children at Maternity and Children Hospital in Indonesia in 2020 ( $n=32)$.

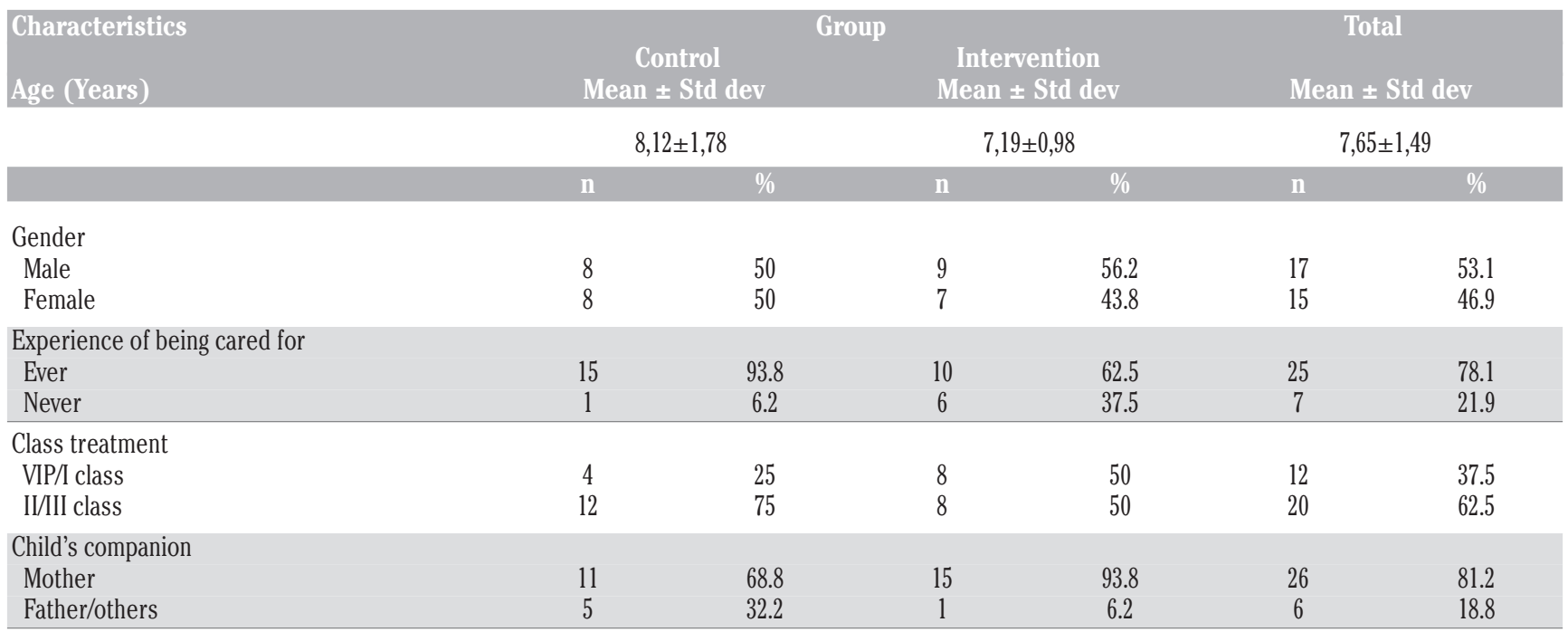


homogeneity test of this research was carried out with an independent t-test on the before-fear score (pretest) between the intervention and control groups. The results obtained from the homogeneity test revealed no significant difference between the two groups, $(\mathrm{p}$-value $=0.635>0.05$, Table 2$)$.

\section{Results}

Fear Score Differences in the intervention group and control group before treatment on school-age children in Maternity and Children Hospital in Indonesia, June-July $2020(n=23)$

The Independent T-test the before fear score (pretest) showed the result had a $p$-value $=0.615>0.05$. Therefore, it can be deduced that there is no significant difference in the before fear scores (pretest) between the intervention and control groups (Table 3).

\section{Difference analysis of the before and after fear score between the intervention and control groups}

The average fear score before the storytelling treatment in the intervention group was 1.61 while the score after the treatment was 0.58 (Table 4). There was a decline in the Intervention Group's fear score, which was 1.03. Further analysis with a Dependent T-test showed that the p-value $=0.001<0.05$. This result highlights that there is a significant difference in both the before and after fear scores, (pretest and posttest). This strongly indicates that storytelling intervention can positively influence the reduction of hospitalization fear among school-age children. There is therefore an increase in the fear score by 0.62 . Further analysis with the Dependent T-test results in a $\mathrm{p}$-value $=0.261>0.05$, meaning that there is no difference in the control group's fear score, before and after the intervention period.

\section{Analysis of the Fear Score Difference between the intervention and control groups after the experimental period}

The overview in Table 5 shows that after a fear score of the intervention group averaged 0.58 while in the control group it was 1.53 . The Independent T-Test showed that the before fear score (pretest) between the intervention and control groups had a pvalue $=0.001<0.05$. This shows that there is a significant difference in the after fear score between the intervention and control groups. This suggests that storytelling intervention has a significant positive effect on the fear of hospitalization score in school-age children.

\section{Analysis of the correlation between the respondent characteristics and after Fear Score (post intervention)}

Following are the results of the analysis between the respondent characteristics and after the fear score (post intervention, Table 6).

Table 2. Table distribution of Fear Scores in school-age children before and after the story telling intervention group and the control group at Maternity and Children Hospital in Indonesia in $2020(n=32)$.

\begin{tabular}{|c|c|c|c|c|}
\hline Fear Scores & Mean & Median & Standard deviation & Minimum-Maximum \\
\hline \multicolumn{5}{|l|}{ Intervention } \\
\hline Before & 1.61 & 1.50 & 0.75 & $0.75-3, .00$ \\
\hline After & 0.58 & 0.63 & 0.39 & $0.00-1.25$ \\
\hline \multicolumn{5}{|l|}{ Control } \\
\hline Before & 1.47 & 1.25 & 0.82 & $0.50-3.00$ \\
\hline After & 1.53 & 1.25 & 0.72 & $0.75-3.00$ \\
\hline
\end{tabular}

Table 3. Table of Fear Score Differences in the intervention group and control group before treatment on school-age children in Maternity and Children Hospital in Indonesia.

\begin{tabular}{lccc} 
Group & Mean & $\begin{array}{c}\text { Fear Score before intervention } \\
\text { Standard deviation }\end{array}$ & P-value \\
Intervention & 1,61 & 0,75 & 0,615 \\
Control & 1,47 & 0,82 & \\
\hline
\end{tabular}

Table 4. The difference between the before and after Fear Score (0-4) between the intervention and control groups in Maternity and Children Hospital in Indonesia, June-July 2020 ( $n=32)$.

\begin{tabular}{|c|c|c|c|c|}
\hline Fear Score & Mean & Standard deviation & Average decline & P-value \\
\hline \multicolumn{5}{|l|}{ Intervention } \\
\hline Before & 1.61 & 0.75 & 1.03 & $0.001^{*}$ \\
\hline After & 0.58 & 0.39 & & \\
\hline \multicolumn{5}{|l|}{ Control } \\
\hline Before & 1.47 & 0.82 & -0.62 & 0.261 \\
\hline After & 1.53 & 0.72 & & \\
\hline
\end{tabular}


Table 6 shows the correlation between age and after the fear score of the respondents. Analysis of the test using the Product Moment Correlation showed a significance value of $0.280>0.05$. Therefore, it can be explained that there is no significant difference between the children's age and the after the fear score (post). The correlation coefficient obtained was 0.197, meaning that the greater the child's age, the higher the fear score. However, the correlation becomes weaker, (unrelated).

Table 7 explains the score of fear after (post) on gender, care experience, class of care, child companion was not found to be found eating with a $\mathrm{P}$ value $>0.05$.

\section{Discussion}

The relationship between age and post-school-age fear scores using the Product Moment Correlation test does not show a significant difference that the higher a person's age, the higher the fear score with the value of correlation strength very weak (unrelated). In contrast to the results of previous studies which showed that the average age of respondents who experienced fear was 5.85 years, while for respondents who did not experience fear, the average age was 8.40 years. ${ }^{14}$ This shows that the higher the age of the respondents, the less fear they are. Heden also stated that the younger the child is, the child's level of fear will be higher than the pain felt due to invasive action. 15 The difference in the results in this study was possible because most respondents were accompanied by mothers where the mother played a very important role in calming the child's psychology, as well as the existence of other sources of distraction such as television, cellphones, and the like that could entertain the child when the intervention was not carried out. Another study states that preschoolers aged 4-5 years are more receptive to distraction using storybooks and animated cartoons to reduce distress than other age groups. ${ }^{16}$

Male and female gender with the fear score obtained $\mathrm{P}$ value $>0.05$, this shows that there is no significant difference. It is different from Ramdaniati's research which stated that girls tend to experience a higher fear of hospitalization than boys. ${ }^{17}$ This difference is possible because the number of study respondents was mostly boys $(53.1 \%)$. This is one of the factors that cannot be avoided in this study because the samples taken are by the inclusion criteria and do not disaggregate based on the sex of the respondent.

While the analysis of care experience with a score of fear obtained $\mathrm{P}$ value $>0.05$, where there was no significant difference between children who had been treated before and those who had never been treated. In line with Ramdaniati's research, ${ }^{17}$ it shows that there is no significant difference in the proportion of fear incidents between respondents who have been treated with those who have never been hospitalized before. Other studies show that anxiety due to hospitalization in children depends on the level of maturity of the child's development, separate history from parents/hospitalization, and the availability of a support system. It is different

Table 5. The difference in the after Fear Score (0-4) between the intervention and control groups in Maternity and Children Hospital in Indonesia, June-July 2020 ( $n=32)$.

\begin{tabular}{|c|c|c|c|}
\hline Group & Average & $\begin{array}{l}\text { After Experimental pe } \\
\text { Standard deviation }\end{array}$ & P-value \\
\hline Intervention & 0.85 & 0.39 & $0.001^{*}$ \\
\hline Control & 1.53 & 0.72 & \\
\hline
\end{tabular}

Table 6. The correlation between the respondents' age and the After Fear Score (0-4) (post intervention) in Maternity and Children Hospital in Indonesia, June-July 2020 (n=32).

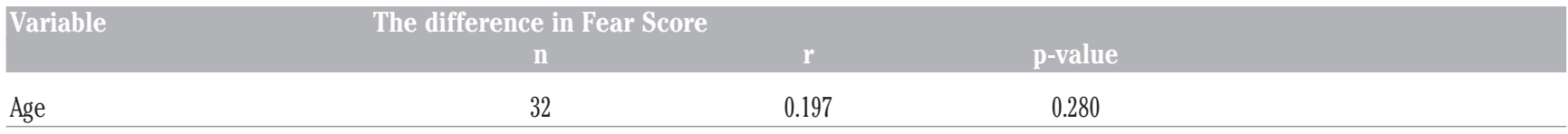

Table 7. The correlation between the sex, hospitalization experience, ward class, and inpatient companion with the after Fear Score $(0-4)$ in Maternity and Children Hospital in Indonesia for the period $2020(n=32)$.

\begin{tabular}{|c|c|c|c|}
\hline Characteristics & n & $\begin{array}{l}\text { sendent ' } \\
\text { T Value }\end{array}$ & n-value \\
\hline $\begin{array}{l}\text { Gender } \\
\text { Male } \\
\text { Female }\end{array}$ & $\begin{array}{l}17 \\
15\end{array}$ & 0.382 & 0.705 \\
\hline $\begin{array}{l}\text { Hospitalization experience } \\
\text { Have experienced } \\
\text { Have never Experienced }\end{array}$ & $\begin{array}{c}25 \\
7\end{array}$ & 1.075 & 0.291 \\
\hline $\begin{array}{l}\text { Ward class } \\
\text { VIP/Class I } \\
\text { Class II/Class III }\end{array}$ & $\begin{array}{l}12 \\
20\end{array}$ & -1.571 & 0.127 \\
\hline $\begin{array}{l}\text { Inpatient companion } \\
\text { Mother } \\
\text { Father/other }\end{array}$ & $\begin{array}{c}26 \\
6\end{array}$ & -0.550 & 0.586 \\
\hline
\end{tabular}


in research that children who have had previous experiences of being treated have a greater level of anxiety and fear than children who have never been treated before. ${ }^{18,19}$

Analysis of the care class with the fear score after the intervention obtained $P$ value $>0.05$ so that there was no difference in the relationship between treatment class and the decrease in the hospitalization fear score. In grade 2 or grade 3 the child care room consists of 3-4 patients in one room so that the child's needs for socialization can still be met.

The results of the analysis of the child's companion with a score of fear after the intervention (post) obtained a $\mathrm{P}$ value $>0.05$. This shows that there is no significant difference between children accompanied by mothers and children accompanied by fathers or others. When a child is sick or in trouble, usually a mother can provide a sense of comfort and calm to her child. ${ }^{20}$ However, the results in this study showed that there was no significant difference between the companion in the hospital whether accompanied by the mother or others regarding the fear experienced by the child. In research related to hospitalization, it is said that the involvement of parents when the child is subjected to an invasive infusion will provide a feeling of calm, comfort and can facilitate children's mastery of the surrounding environment. ${ }^{7}$ Other studies suggest that parental factors such as parental anxiety, previous pain history, and parental stress levels can limit the positive influence on parental involvement in care. ${ }^{21}$ So that the involvement of families/mothers can provide socio-cultural and environmental comfort for children. Socio-cultural comfort can be obtained by children from children's interpersonal relationships with family and society, while environmental comfort is related to the external environment, conditions, and influences around it. 22

While the description of the fear score in school-age children before and after the intervention in each intervention group and control group, namely that the intervention group saw a decrease in fear scores by 1.03 from 1.61 to 0.58 . The results of the $\mathrm{T}$ Dependent analysis obtained $\mathrm{p}$-value $=0.000<0.05$, so Ho was rejected, which means that there is a significant difference in the fear score before (pretest) and after (posttest) giving the storytelling intervention. Nurses in providing storytelling to children can reduce the child's level of fear while being hospitalized. This is reinforced by Coia's research which explains that nurses who use a fun approach before intervening can make children feel comfortable and this can reduce the level of anxiety and fear of children while in the hospital. ${ }^{23}$ In line with the results of related research, it also states that storytelling and play therapy has a positive effect on good emotions in children, thus contributing to both their physical and emotional well-being and to their recovery. 24,25 However, in the control group, the results of the further analysis with the Dependent T-test obtained P-value $=0.261>0.05$, so that Ho was accepted. Thus, in the control group, there was no change in fear scores between before and after the intervention period.

The results of the fear score assessment in the intervention group and the control group obtained a difference in score with pvalue $=0.000<0.05$, so Ho was rejected, meaning that there was a significant difference between the difference in fear scores in the intervention group and the control group. Thus, it can be concluded that the existence of a storytelling intervention has a positive effect on reducing children's fear scores while in the hospital. This is in line with the results of previous studies which show that there are significant differences related to happiness and relaxation in the intervention group who received storytelling and imagination guidance compared to the control group. ${ }^{26}$

In connection with the COVID-19 pandemic affecting the entire world, including Indonesia, many hospitals have prohibited researchers from directly obtaining primary patient data. The con- dition of the care class II and class III has the potential to disrupt or interfere with the storytelling interventions given to the respondents but the number of the hospitalized patients was significantly reduced due to the pandemic. In the control group, the researcher did not control other activities carried out during the intervention period. This implies that if there were other distraction activities carried out by respondents these may have affected the measurement process and the results may contain bias. However, the researcher had anticipated this by explaining to the parents so that the respondents would temporarily stop using their cellphones during the research process.

The result of this research can be a consideration for nurses to provide storytelling in nursing intervention by involving parents in its implementation according to the concept of family centered care. This research will add to the library collection in nursing education, and add information or nursing science literature and can become the basic data for further research.

\section{Conclusions}

Intervention stories that affect reducing children's fear were found in the intervention group before and after the storytelling intervention compared to the control group. Meanwhile, respondents such as age, gender, experience who have been treated, class of care, and care companion are not afraid of children who are undergoing treatment in the hospital.

Nurses can apply storytelling interventions in providing nursing care to the patient's child. Storytelling interventions are easy and inexpensive to do whenever and wherever the patient is being treated as long as the patient's health condition allows. In future studies, it is hoped that the storytelling will develop in a more varied way with more varied methods and with a larger number of samples as well as a different research location by paying attention to a special room when presenting stories to avoid other distractions.

It is expected that the nursing service managers can use the results of this research as a reference to involve storytelling in nursing interventions when caring for pediatric patients. Storytelling interventions are easy and inexpensive to deliver whenever and wherever the patient is treated, as long as the patient's health condition allows. Nurses can take advantage of the results of this research to develop their potential by applying the knowledge in a practical setting and can modify the implementation of storytelling interventions in the services by adjusting to the available facilities and tools.

\section{References}

1. Anandhukrishnan TG, Sivan A, Difna BK, et al. Effectiveness of play on anxiety among hospitalized children. Asian J Nurs Educ Res 2018;8:225-9.

2. Kaluas I, Ismanto AY, Kundre RM. Perbedaan terapi bermain puzzle dan bercerita terhadap kecemasan anak usia prasekolah (3-5 tahun) selama hospitalisasi di ruang anak RS tk. III. R. W. Mongisidi Manado. e-Kp: eJurnal Keperawatan 2015;3:1-8.

3. Merlin SSA, Jebakumari SR, Shini. Effectiveness of play therapy on anxiety among hospitalized preschool children. Asian J Nurs Educ Res 2019;9:193-6.

4. Hockenberry MJ, Wilson D. Wong's nursing care of infants and children. 10th ed. New York: Mosby; 2014: p. 1323-30.

5. Nurmashitah, Purnama A. Medical play dalam menurunkan 
respon kecemasan anak usia prasekolah yang mengalami hospitalisasi di ruang rawat inap anak. Jurnal Ilmiah Ilmu Keperawatan Indonesia 2018;8:516-21.

6. Sekhavatpour Z, Khanjani N, Reyhani T, et al. The effect of storytelling on anxiety and behavioral disorders in children undergoing surgery: a randomized controlled trial. Pediatr Health Med Therap 2019;10:61-8.

7. Legi JR, Sulaeman S, Purwanti NH. Pengaruh storytelling dan guided-imagery terhadap tingkat perubahan kecemasan anak usia prasekolahyang dilakukan tindakan invasif. JOTING J Telenursing 2019;1:145-56.

8. Hsieh YC, Cheng SF, Tsay PK, et al. Effectiveness of cognitive-behavioral program on pain and fear in school-aged children undergoing intravenous placement. Asian Nurs Res 2017;11:261-7.

9. Anggerainy SW, Wanda D, Nurhaeni N. Music therapy and story telling: nursing interventions to improve sleep in hospitalized children. Compr Child Adolesc Nurs 2019;42:82-9.

10. Li WHC, Chung JOK, Ho KY, Kwok BMC. Play interventions to reduce anxiety and negative emotions in hospitalized children. BMC Pediatr 2016;16:36.

11. Collins RD. Healing through story: exploring the use of storytelling preaching as a means for healing a congregation. [Unpublished Thesis]. Atlanta: Mercer University; 2018.

12. Dehghan F, Jalali R, Bashiri H. The effect of virtual reality technology on preoperative anxiety in children: a Solomon four-group randomized clinical trial. Perioper Med 2019;8:5.

13. Mechtel M, Stoeckle A. Psychosocial care of the pediatric oncology patient undergoing surgical treatment. Semin Oncol Nurs 2017;33:87-97.

14. Ramdaniati S. Analisis determinan kejadian takut pada anak pra sekolah dan sekolah yang mengalami hospitalisasi di ruang rawat anak RSU BLUD dr. Slamet Garut. [Unpublished Thesis]. Depok: Universitas Indonesia; 2011.

15. Hedén L, von Essen L, Ljungman G. Children's self-reports of fear and pain levels during needle procedures. Nursing Open 2020;7:376-82.
16. Kuo HC, Pan HH, Creedy DK, Tsao Y. Distraction-based interventions for children undergoing venipuncture procedures: a randomized controlled study. Clin Nurs Res 2018;27:467-82.

17. Shahriari M, Dehghan M, Pahlavanzadeh S, Hazini A. Effects of progressive muscle relaxation, guided imagery and deep diaphragmatic breathing on quality of life in elderly with breast or prostate cancer. J Educ Health Promot 2017;6:1.

18. Cardinal FG, Arroyo GM, Magbanua S, Sajnani AK. Measurement of anxiety in 3-9 year old children receiving nursing intervention. J Caring Sci 2017;6:293-302.

19. Şahin ÖÖ, Topan A. Investigation of the fear of 7-18-year-old hospitalized children for illness and hospital. J Relig Health 2019;58:1011-23.

20. Pannier ST, Mann K, Warner EL, et al. Survivorship care plan experiences among childhood acute lymphoblastic leukemia patients and their families. BMC Pediatr 2019;19:111.

21. Karlsson K, Englund ACD, Enskär K, et al. Experiencing support during needle-related medical procedures: a hermeneutic study with young children (3-7 years). J Pediatr Nurs 2016;31:667-77.

22. Martha RA. Nursing theorists and their work. 8th ed. St. Louis, Missouri: Mosby Inc.; 2014.

23. Coia BJ. A description of approachable nurses: the voice of the hospitalized child. [Thesis]. Rhode Island: University of Rhode Island; 2017.

24. Brouzos A, Vassilopoulos SP, Moschou K. Utilizing storytelling to promote emotional well-being of children with a distinct physical appearance: the case of children who wear eyeglasses. Eur J Counselling Psychol 2016;4:62-76.

25. Koukourikos K, Tzeha L, Pantelidou P, Tsaloglidou A. The importance of play during hospitalization of children. Mater Sociomed 2015;27:438-41.

26. Piasai K, Phumdoung S, Wiroonpanich W, Chotsampancharoen T. A randomized control trial of guidedimagination and drawing-storytelling in children with cancer. Pacific Rim Int J Nurs Res 2018;22:386-400. 